\title{
CHEMICAL PROFILE OF THE ENDOCARP AND EXOCARP OF YELLOW MONKEY COLA (COLA LEPIDOTA)
}

\author{
V. N. OSABOR, F. I. BASSEY AND K. A. IBE \\ (Received 9 September 2014; Revision Accepted 5 December 2014)
}

\begin{abstract}
The chemical profile of the Endocarp and Exocarp of yellow monkey cola (Cola lepidota) were investigated using chemical analysis. The results of proximate analysis showed that the endocarp has the following compositions: moisture $(20.00 \pm 0.10 \% \mathrm{~W} / \mathrm{W})$, ash $(4.00 \pm 0.11 \% \mathrm{DM})$, crude fibre $(36.00 \pm 0.12 \% \mathrm{DM})$, crude fat $(16.00 \pm 0.11 \% \mathrm{DM})$, crude protein $(22.84 \pm 0.12 \% \mathrm{DM})$, available carbohydrate $(21.16 \pm 0.12 \% \mathrm{DM})$ and the energy value $(320.00 \pm 0.01 \mathrm{kcal} / 100 \mathrm{~g})$ while the exocarp contained moisture $(22.00 \pm 0.12 \% \mathrm{~W} / \mathrm{W})$, ash $(8.00 \pm 0.11 \% \mathrm{DM})$, crude fibre $(7.00 \pm 0.11 \% \mathrm{DM})$, crude fat $(12.50 \pm 0.10 \% \mathrm{DM})$, crude protein $(1.58 \pm 0.11 \% \mathrm{DM})$ available carbohydrate $(70.92 \pm 0.11 \% \mathrm{DM})$ and the energy value $(402.42 \pm 0.10 \mathrm{kcal} / 100 \mathrm{~g})$. The endocarp mineral elements analysis revealed that sodium $(0.033 \pm 0.21 \mathrm{mg} / 100 \mathrm{~g})$, lead $(0.004 \pm 0.12 \mathrm{mg} / 100 \mathrm{~g})$ cadmium $(0.002 \pm 0.11 \mathrm{mg} / 100)$ calcium $(78.35 \pm 0.12$ $\mathrm{mg} / 100 \mathrm{~g})$, zinc $(55.32 \pm 0.12 \mathrm{mg} / 100)$, phosphorus $(0.068 \pm 0.12 \mathrm{mg} / 100 \mathrm{~g})$, iron $(47.45 \pm 0.11 \mathrm{mg} / 100 \mathrm{~g})$ and manganese $(0.09 \pm 0.31 \mathrm{mg} / 100 \mathrm{~g})$ while the exocarp mineral elements analysis revealed that sodium $(0.011 \pm 0.11 \mathrm{mg} / 100 \mathrm{~g})$, magnesium $(0.02 \pm 0.11 \mathrm{mg} / 100 \mathrm{~g})$, lead $(0.02 \pm 0.12 \mathrm{mg} / 100 \mathrm{~g})$, cadmium $(0.03 \pm 00.12 \mathrm{mg} / 100 \mathrm{~g})$, zinc $(12.16 \pm 0.12 \mathrm{mg} / 100 \mathrm{~g})$, potassium $(17.21 \pm 0.12 \mathrm{mg} / 100 \mathrm{~g})$, calcium $(22.55 \pm 0.11 \mathrm{mg} / 100 \mathrm{~g})$, iron $(11.21 \pm 0.32 \mathrm{mg} / 100 \mathrm{~g})$ and manganese $(0.003 \pm 0.12 \mathrm{mg} / 100 \mathrm{~g})$. The mineral element concentrations of cobalt, nickel and mercury were not detected in both endocarp and exocarp of cola lepidota. The toxicants composition analysis of endocarp revealed that hydro-cyanide, soluble oxalate and phytic acids contents were $0.54 \pm 0.01,8.65 \pm 0.12$ and $5.50 \pm 0.12 \mathrm{mg} / 100 \mathrm{gDM}$ respectively, while the exocarp revealed $0.09 \pm 0.12,0.01 \pm 0.11$ and $4.00 \pm 0.11 \mathrm{mg} / 100 \mathrm{gDM}$ respectively. The results of phytochemical screening of water extract (WE) of both endocarp and exocarp of cola lepidota shows the presence of polyphenols, reducing sugars, cardiac glycosides and saponins and the absence of phlobatannins, tannins, anthranoids and anthraquinones. The petroleum ether extract (PEE) revealed the presence of cardiac glycosides, saponins, flavonoids, polyphenols, and reducing sugars and also the absence of alkaloids, tannins, phlobatanins, anthranoids and authraquinones.
\end{abstract}

KEYWORDS: Cola lepidota, Proximate Composition, Minerals, Nutritional and Anti-nutritional

\section{INTRODUCTION}

In Africa many studies have indicated that west and central sub-regions have been known to holds a varieties of cola species: cola nitida, red cola, cola acuminate, white cola and cola lepidota, yellow cola (Etonihu et al., 2013). Cola lepidota fruit have long been identified as a primary fruit of the forest region of southsouth Nigeria. The fruits are consumed in large quantities by man, woman and children alike largely because of the huge nutritional potentials and tasty pulp (Burkill, 2000). The economic importance of Cola lepidota fruit to local dwellers cannot be over emphasized. Fruit trees in Africa constitute one of the best tools for preventing diseases caused by lack or insufficient supply of vitamins in diet (Lovett et al., 2006). Fruit are good source of protein, fat, carbohydrate and minerals. Nutritionally, they are believed to contain beta carotene which act as antioxidant (Bello et al., 2008). Recent findings have revealed that fruits contain bioactive compounds such as polyphenols, alkaloids, saponins and anthraquinones etc which have some medicinal potential (Mohammed et al., 2011). Fruit also used as food contains a variety of organic compounds which at certain critical levels have anti-nutritional components such as oxalate, phytic acid and hydrocyanic acid (Omorayi and Dilworth, 2007). Therefore, these harmful components must be removed before their consumption. Oladokun (1988) investigated the pod of Cola lepidota fruits and his findings revealed that $85 \%$ of the pod contains $0-2$ nuts in a pod while the mean nut number per pod was 3.0. Correlation analysis showed highly significant correlation between pot weight and number of other pot characteristic such as length, nut number per pod and tests weight. Regression also showed significant results for the pair of these characteristics. Cola lepidota commonly called yellow monkey cola are identified by various local names in south-south, Nigeria. Achicha or Orchiricha in Igbo speaking states and Ndiya in Efik as well as the Ibibios of Akwa-lbom State, Nigeria. Cola lepidota is a small tree reaching $20 \mathrm{~m}$ tall and $20 \mathrm{~cm}$ in diameter often branching low, leaves are digital and the leaflets are up to $50 \mathrm{~cm}$ long. (Hatchison and Dalziel, 1958). Consumption of Cola type beverage is not correlated with any heart disease. The bark of Cola gigamteam is

V. N. Osabor, Department of Pure and Applied Chemistry, University of Calabar, Calabar, Nigeria.

F. I. Bassey, Department of Chemistry, Federal University of Petroleum Resources, Efurum, Delta State, Nigeria.

K. A. Ibe, Department of Chemistry, Federal University of Petroleum Resources, Efurum, Delta State, Nigeria. 
used to treat yaws while that of Cola lateritica (red monkey cola) is very effective in the treatment of wounds. The bark of Cola nitida is used in the management of excessive appetite and fracture. The cotyledon is used for the treatment of herpers and the bark is used in the treatment of dystocia (Mashana et al., 2000). In the present study the chemical profile of endocarp and exocarp of yellow monkey cola obtained from Cross River State are investigated and reported.

\section{MATERIALS AND METHODS}

Sample collection and preparation: Fresh samples of Cola lepidota were collected from Okoroba farm plantation in Ikom Local Government area of Cross River State. The samples were identified by a Herbarium in Botany Department, University of Calabar, Calabar, Nigeria. The samples were cured by the traditional method of wrapping in fresh banana leaves to reduce moisture loss. The fruits were washed with distilled water and the exocarp and endocarp removed. The edible endocarp was separated from the seeds. The endocarp and exocarp were chopped into pieces using knife with steel blades and spread separately on a wooden board and placed in an oven. The dried samples were ground into powder with the aid of a blender, sieved and stored in desiccators until required for analysis.

\section{APPARATUS AND REAGENTS:}

A Pye-unican Atomic Absorption Spectrophotometer with acetylene flame was used to analyse for calcium, iron, manganese, magnesium, zinc and copper as described by A.O.A. C. (1990) while sodium and potassium were determined by flame photometer (Gallen Kamp) as described by Vogel (1962) Emack concentrated volumetric solutions were used as standard metallic ions solution for the calibrations. All reagents used were of Analytical grade and the water used was double distilled.

\section{PROXIMATE ANALYSIS:}

Proximate analysis was carried on various food parameters in endocarp and exocarp of Cola lepidota samples. Moisture, ash, ether extract (EE), crude fibre (CF) and nitrogen free extract (NFE) were determined by the method of A.O.A.C (1990). The estimation of available carbohydrate $(A C)$ was done by difference as $\mathrm{CHO}=100-(\%$ Ash.$+\%$ crude protein $+\%$ crude fibre + crude fat). The crude protein content was calculated by multiplying the nitrogen content by 6.25 while the energy value (Kcal.) was obtained by $(\% \mathrm{CHO} \times 4)+(\% \mathrm{CP} \times 4)+$ (\% CLx9) where $\mathrm{CHO}$ stands for carbohydrates, CP stands for crude protein and CL stands for crude lipid (Hassan et al., 2008).

\section{TOXICANT ANALYSIS}

Hydrocyanic acid (HCN) was estimated by the alkaline titration method of (A.O.A.C 1975), oxalate was determined by the method of (Dye, 1956) while phytic acid was extracted using $3 \%$ trichloroacetic acid. The extracts were prepared according to the method described by Wheeler and Ferrel (1977). The absorbance was read at $480 \mathrm{~nm}$, while phytic acid was calculated by employing the method of Saturdi and
Suckles (1985). On the basis that six atoms of phosphorus are contained in one molecule of phytic acid giving a 1:3.55 phosphorus: phytic molecule ratio (phytic acid $=\mathrm{C}_{6} \mathrm{H}_{18} \mathrm{O}_{24} \mathrm{P}_{6}$ ).

\section{SAMPLES DIGESTION}

The pulverized samples $(5 \mathrm{~g})$ was weighed into a beaker, $30 \mathrm{ml}$ of concentrated perchloric acid and $5 \mathrm{ml}$ of concentrated nitric acid were added and shaked for few minutes. The content was heated with continuous stirring until the mixture turned white. The digest was diluted with $50 \mathrm{ml}$ of deionizer water and heated for few minutes. The mixture was allowed to cool and transferred into a $100 \mathrm{ml}$ volumetric flask and made up to the mark (Osabor et al., 2010).

\section{MINERAL ELEMENT ANALYSIS}

The mineral elements were determined by first wet ashing the samples (A.OA.C 1990, Osabor et al., 2010). Sodium and potassium were determined by flame photometer (Gallen Kamp). Calcium, manganese, magnesium copper, zinc and iron were determined by Atomic Absorption Spectrophotometer (Pye-Unican). Phosphorus was determined by Vanado molybdate colorimetric method as described by James (1996)

\section{PHYTOCHEMICAL SCREENING}

Phytochemical screening includes alkaloids, saponins, flavonoids, phlobatanins, cardiac glycosides, tannins and anthraquinones were screened by the method of and Harborne (1973) and Kotoky et al (2005).

\section{RESULTS AND DISCUSSION}

Table I show the results of proximate compositions of the exocarp and endocarp of Cola lepidota. These includes those of moisture, ash, crude fibre (CF), protein, crude fat and carbohydrate content. The moisture content was found to be $22.06 \pm 012 \% \mathrm{~W} / \mathrm{W}$ weigh/weight for exocarp while the endocarp moisture content was $20.00 \pm 0.10 \% \mathrm{~W} / \mathrm{W}$. The ash content of exocarp was $8.0 \pm 0.11 \% \mathrm{DM}$ while that of the endocarp was $4.00 \pm 0.11 \% \mathrm{DM}$ (Dry matter). The crude protein content was $1.58 \pm 0.11 \% \mathrm{DM}$ for the exocarp while that of the endocarp was $22.84 \pm .12 \% \mathrm{DM}$. The crude fibre value was $7.58 \pm 0.12 \% \mathrm{DM}$ for the exocarp while that of the endocarp was $36.00 \pm 0.12 \% \mathrm{DM}$. The carbohydrate content of the exocarp was found to be $70.92 \pm 0.11 \% \mathrm{DM}$ while that of the endocarp was reported to be $21.16 \pm 0.12 \% \mathrm{DM}$.

Table 2 Show the results of toxicant compositions of exocarp and endocarp of cola lepidota. The levels of toxicant composition of phytic acid, hydrocyanic acid and soluble oxalate in exocarp are $0.09 \pm 0.12,6.01 \pm 0.11$ and $4.00 \pm 0.11 \mathrm{mg} / 100 \mathrm{gDM}$ respectively while that of endocarp are $0.54 \pm 0.11,8.65 \pm 0.12$ and $5.50 \pm 0.12$ $\mathrm{mg} / 100 \mathrm{gDM}$ respectively. The levels of phytic acid was very low while that of hydrocyanic acid and soluble oxalate were moderately high on both exocarp and endocarp samples studied.

Table 3 Show the results of mineral elements composition of exocarp and endocarp of Cola lepidota samples studied. The exocarp mineral elements composition ranged from $0.003 \pm 0.12$ for manganese to 
$22.55 \pm 0.11 \mathrm{mg} / 100 \mathrm{~g}$ for calcium while that of endocarp ranged from $0.002 \pm 0.11 \mathrm{mg} / 100 \mathrm{~g}$ for cadmium to $78.35 \pm 0.11 \mathrm{mg} / 100 \mathrm{~g}$ for calcium.

Table 4 Shows the results of phytochemical screening of both exocarp and endocarp of cola lepidota samples studied. The results obtained revealed the presence of cardiac glycosides, saponins, flavonoids and reducing sugars in water extract (WE) and petrolcum ether extract (PEE) of exocarp and endocarp of cola lepidota.

Table 1: Proximate compositions of endocarp and exocarp of cola lepidota

\begin{tabular}{lll}
\hline Parameters & Exocarp & Endocarp \\
\hline Moisture(\%) $(\%)$ & $22.00 \pm 0.12$ & $20.00 \pm 0.10$ \\
Ash protein(\%) & $8.00 \pm 0.11$ & $4.00 \pm 0.11$ \\
Crude & $1.58 \pm 0.11$ & $22.84 \pm 0.12$ \\
Crude fibre (\%) & $7.58 \pm 0.12$ & $36.00 \pm 0.12$ \\
Crude fat (\%) & $12.50 \pm 0.10$ & $16.00 \pm 0.11$ \\
Carbohydrate (\%) & $70.92 \pm 0.11$ & $21.16 \pm 012$ \\
Energy value (kcal) & $402.42 \pm 0.42$ & $320.00 \pm 0.01$ \\
\hline
\end{tabular}

The data are mean value \pm standard S.D deviation of triplicate determinations; $\%$ crude protein $=\% \mathrm{~N} \times 6.25$

Table 2: Toxicant compositions $(\mathrm{mg} / 100 \mathrm{~g})$ of endocarp and exocarp of Cola lepidota.

\begin{tabular}{lll}
\hline Parameters & Exocarp & Endocarp \\
\hline Phytic acid & $0.09 \pm 0.12$ & $0.54 \pm 0.11$ \\
Hydrocyanic acid & $6.01 \pm 0.11$ & $8.65 \pm 0.12$ \\
Soluble oxalate & $4.0 \pm 0.11$ & $5.50 \pm 0.13$ \\
\hline
\end{tabular}

The data are mean value \pm S.D of triplicate determinations.

Table 3: Metals content of exocarp and endocarp of cola lepidota $(\mathrm{mg} / 100 \mathrm{~g})$.

\begin{tabular}{|l|l|l|}
\hline Metals & Exocarp & Endocarp \\
\hline Sodium (Na) & $0.01 \pm 0.11$ & $0.033 \pm 0.21$ \\
\hline Magnesium (Mg) & $0.02 \pm 0.11$ & ND \\
\hline Lead (Pb) & $0.02 \pm 0.12$ & $0.04 \pm 0.12$ \\
\hline Cadmium (Cd) & $0.03 \pm 0.12$ & $0.002 \pm 0.11$ \\
\hline Zinc $(\mathrm{Zn})$ & $12.16 \pm 0.12$ & $55.32 \pm 0.12$ \\
\hline Potassium (K) & $17.21 \pm 0.12$ & $36.32 \pm 0.57$ \\
\hline Calcium (Ca) & $22.55 \pm 0.11$ & $78.55 \pm 0.11$ \\
\hline Iron (Fe) & $11.21 \pm 0.32$ & $47.45 \pm 0.11$ \\
\hline Manganese (Mg) & $0.003 \pm 0.12$ & $0.09 \pm 0.31$ \\
\hline Phosphorus (P) & ND & $0.068 \pm 0.12$ \\
\hline Nickel (Ni) & ND & BDL \\
\hline Mercury (Hg) & BDL & BDL \\
\hline
\end{tabular}

Data are mean value \pm S.D of triplicate determinations.

$\mathrm{ND}=$ not detected

$\mathrm{BDL}=$ below detectable limit. 


\begin{tabular}{|c|c|c|c|c|}
\hline Parameters & $\begin{array}{l}\text { Water extract } \\
\text { endocarp (WE) }\end{array}$ & $\begin{array}{lr}\text { Petroleum r ether } \\
\text { extract } \\
\text { (PEE) }\end{array}$ & $\begin{array}{l}\text { Water extract } \\
\text { exocarp (WE) }\end{array}$ & $\begin{array}{lr}\text { Petroleum } & \text { ether } \\
\text { extract } & \text { exocarp } \\
\text { (PEE) } & \\
\end{array}$ \\
\hline Cardiac glycosides & + & + & ++ & + \\
\hline Alkaloids & - & - & - & - \\
\hline Saponins & + & ++ & + & - \\
\hline Tannins & - & - & - & - \\
\hline Flavonoids & + & - & - & + \\
\hline Polyphenols & ++ & ++ & ++ & ++ \\
\hline Reducing Sugars & ++ & + & + & + \\
\hline Phlobatananins & - & - & - & - \\
\hline Anthranoids & - & - & - & - \\
\hline Anthraquinones & - & - & - & - \\
\hline
\end{tabular}

$$
\begin{aligned}
& +=\text { Present in moderate quantity } \\
& ++=\text { Present in large quantity } \\
& +=\text { Absent. }
\end{aligned}
$$

\section{DISCUSSION}

Present study was carried out to justify the utilization of fruits of cola lepidota for its nutritional potential and physiological utility. The result of the moisture content for Cola lepidota is presented in Table 1. The results obtained was $22.00 \pm 0.12 \%$ DM for exocarp and $20.00 \pm 0.10 \% \mathrm{w} / \mathrm{w}$ for endocarp. The moisture contents of Cola lepidota is low when compared to $62.50 \pm 0.08 \% \mathrm{w} / \mathrm{w}$ of Cola nitida (Red kola) and $63.80 \pm 0.08 \% \mathrm{w} / \mathrm{w}$ for Cola acuminate (white kola) by Etonihu et al (2013). The moisture contents of food is usually used as a measure of stability and susceptibility to microbial attack (Scott, 1980). The ash contents of cola lepidota is given in table. The Cola lepidota endocarp ash content is $4.00 \pm 0.11 \% \mathrm{DM}$ and exocarp $8.00 \pm 0.12 \% \mathrm{DM}$. The value of the ash contents obtained in this study is higher than $2.44 \pm 0.08 \% \mathrm{DM}$ reported by Etonihu et al (2013) for cola nitida (red kola). The high ash levels of the exocarp indicates that mineral elements are likely to be concentrated in the exocarp than the endocarp (Oyeyede, 2005). The crude fibre contents were $36.10 \pm 0.18 \% \mathrm{DM}$ and $7.56 \pm 0.12 \% \mathrm{DM}$ for endocarp and exocarp respectively. The endocarp contains high fibre value than the exocarp respectively. Fibre in nutrition helps in the maintenance of health as it expands the internal walls of the colon, eases the passage of waste products and acts as anti constipatory agent. Low fibre intake is recommended for infants and pre-school children as high intake is implicated in the irritation of gut mucosa and gut perturbation (Eromosele and Eromosele 1991, Bello et al., 2008). The crude fat contents of exocarp and endocarp of cola lepidota is presented in Table 1. The results obtained are
$16.00 \pm 0.11 \% \mathrm{DM}$ for exocarp and $12.50 \pm \mathrm{DM}$ for endocarp.

The crude fat content is low in the exocarp samples. On the basis of the present investigation, the fat content is higher than $7.80 \pm 0.16 \%$ reported by Etonihu et al (2013) for Cola nitida (red cola). Fats are essential because they provide the body with maximum energy (Dreon et al., 1990). The crude protein contents were $22.80 \pm 0.12 \%$ for endocarp and $1.50 \pm 0.11 \%$ for the exocarp. The protein contents of the endocarp was higher than the exocarp samples. The exocarb results obtained from this study compared favourably well with $1.91 \pm 0.01 \%$ obtained for Cola nitida reported by Etonihu et al (2013) for Cola acuminate (white kola). Protein are essential components of the diet needed for survival, their basic function in nutrition is to supply adequate amounts of required amino acids (Pugalenthi et al., 2004). Deficiency of protein in diet results in abnormal swelling of the body, growth retardation and muscle wasting (Zarkada and Voldeng, 1997). The daily protein requirement for children and adults are 23-26 and 45$56 \mathrm{~g}$ respectively (NRC, 1974). The carbohydrate values were $21.16 \pm 0.12 \%$ for endocarp and $70.92 \pm 0.11 \%$ for exocarp. The exocarp sample has higher carbohydrate content compared to the endocarp. The value obtained from this study compared favourably well with $23.73 \pm 1.07 \%$ reported for cola acuminate by Etonihu et al (2013). The results of toxicants composition is presented in table 2 . The phytic acid values were $0.09 \pm 0.12$ and $0.54 \pm 0.11 \mathrm{mg} / 100 \mathrm{~g}$ for exocarp and endocarp. The phytic acids levels were low in both samples studies. The hydrocyanic acid $(\mathrm{HCN})$ contents were found to be $6.01 \pm 0.11$ and $8.65 \pm 0.12 \mathrm{mg} / 100 \mathrm{~g}$ for the exocarp and endocarp which are extremely below 
the lethal dose for man 50-60 mg/100g body weight/day.

The soluble oxalate contents were relatively low in all the samples studied. The values of $4.00 \pm 0.11$ and $5.50 \pm 0.13 \mathrm{mg} / 100 \mathrm{~g}$ for the exocarp and endocarp samples were very below the toxic levels of $2.5 \mathrm{~g}$ oxalate (Munro and Bassir, 1969). Eastwood (1986) has reported that consumption of oxalate can result in corrosive gastroenteritis, shock, convulsive symptoms, low plasma and renal disorder. The toxicant constituents such as phytic acid, hydrocyanate and soluble oxalates are known to inhibit complete absorption of many mineral elements (Oguntona et al., 1998). The results of the mineral elements composition of cola lepidota is presented in table 3 . The elemental composition showed increased levels in Zinc $(\mathrm{Zn})$, Potassium (K), Calcium $(\mathrm{Ca})$, and iron (Fe) and low levels in sodium $(\mathrm{Na})$, Magnesium (Mg), Cadmium (Cd), Phosphorus (P) and Manganese (Mn). Zinc is the second most abundant element found in the endocarp of the fruit is said to be an essential trace element for protein and nucleic acid synthesis and normal body development. It is also very essential during period of rapid growth in children and recovery from sickness (Mohammed et al., 2011). High levels of potassium in the body has been reported to increase iron utilization (Adeyeye, 2002). Arinathan et al (2003) reported that high concentration of potassium is beneficial to people taking diuretic to control high blood pressure. The result of calcium analysis obtained from this study is represented in table 3 . Calcium is the most predominant element in the endocarp of Cola lepidota. Calcium is required in the body for normal growth of bones and teeth (Robinson, 1978). The result of iron analysis that the endocarp contained $47.45 \mathrm{mg} / \mathrm{l00g}$ and exocarp $11.21 \mathrm{mg} / \mathrm{l00g}$.

$\mathrm{NRC}(1974)$ recommended allowance of 10 $18 \mathrm{mg} /$ day for both children and adults. This implies that cola lepidota is comparatively rich in iron. Iron is needed for red blood cells formation and deficiency in iron leads to iron deficiency anaemia. The results of phytochemical screening of exocarp and endocarp of Cola lepidota. Table 4 shows the presence of cardiac - glycosides in moderate quantities in the sample. Ukpong and Akpan (2011) reported the presence of cardiac glycoside in cocoyam inflorescence. Cardiac glycosides are naturally occurring drugs in plants known for their toxic and pharmacological activities especially in the heart (Harborne, 1973). It has been used as active ingredients in herbal medicine in the treatment of a weaken heart. (Trease and Evans, 1996). It is also used therapeutically in the administration of related heart failure disorder. Osabor et al (2010) has reported the presence of cardiac glycosides in the leaves of Diplazium sumatti leaves. Saponins were found in large quantities in the sample studied. Saponins are very useful in medicine and pharmaceutical industries in the manufacture of insecticides, vaccines and synthesis of steroidal hormones (Gee et al., 1989) saponins have outstanding characteristics, the aqueous extract froth greatly. This is the reason for their used in detergents. Reducing sugars were also found in moderate quantities in the samples studied.

Polyphenols was found in large quantity in both water and petroleum ether extract. Polyphenols are compounds that have a hydroxyl group directly attached to the benzene ring. They are structurally similar to alcohol but are much stronger acids. Polyphenols helps in contracting the blood capillaries and prevent certain hemorrhages (Solomon and Crag, 1998).

\section{CONCLUSION}

From this research Cola lepidota endocarp contains high amount of fibre, moderate levels of moisture, fat and protein. While the exocarp contains high amount of carbohydrate, moderate levels of moisture, ash, fibre and very low levels of protein.

The toxicants composition analysis revealed low levels of toxicants in both samples studied.

The mineral elements composition showed increased levels in potassium, iron, zinc and calcium. This mineral element are needed by the body for proper functioning.

The phytochemical screening results showed the presence of cardiac glycosides, saponins, flavonoids, polyphenols and reducing sugars in both extracts. These bioactive compounds found in the extract of Cola lepidota are used for therapeutic purposes.

\section{REFERENCES}

Adeyeye, E. I., 2002. Determination of the Chemical Composition of the Nutritionally Valuable Parts of Male and Female Common West African Fresh Water Crab (Sudananoules africanus). International Journal of Food Sciences and Nutrition, 53: 189 - 196.

Arinanthan, V., Mohan, V. R and Britto, A. J., 2005. Chemical Composition of Certain Tribal Pulses in South India. International Journal of Food Sciences and Nutrition, 3:103-107.

A. O. A. C., 1975. Official Methods of Analysis $\left(11^{\text {th }}\right.$ ed $)$ Association of Analytical Chemists, Washington D. C.

A. O. A. C., 1990. Official Methods of Analysis $\left(15^{\text {th }}\right.$ ed $)$ Association of Analytical Chemists, Arlingon.

Bello, M. O., Farade, O. S., Adewusi, R. A and Olawore, N. O., 2008. Studies of Some Lesser Known Nigerian fruits. African Journal of Biotechnology 7, (1): $3972-3979$.

Burkill, H. M., 2000. The useful Plants of West Tropical Africa. Loudon, Royal Botanical Garden, United Kingdom.

Dreon, D. M., Vranizan, K. M., Krauss, R. M and Wood,

P. D., 1990. The Effects of Poly Unsaturated Fat and Monosaturated Fat on Plasma, Lipoproteins. Journal of American Medical Association 263: 2462.2465

Dye, V. B., 1956. Chemical studies on Halogeton glumeratus, weed, 4:55 - 60

Eastwood, T., 1986. Oxalate in: Toxicants Occurring Naturally in Foods. Washington, DC. Academy of Science. 
Etonihu, A. C., Adam, H and Nweze, N. O., 2013. Chemical Analysis of Some Nigerian Species of Cola nitida, Cola acuminate and Gercinia cola. Proceedings of the $36^{\text {th }}$ Annual Conference of Chemical Society of Nigeria (CSN). 313 -317 .

Eromosele, I. C and Eromosele, C. O., 1991. studies on the Chemical Composition and physi cochemical Properties of Seeds of Some used plants. Plant Food for Human Nutrition. 43: 251 $-258$.

Gee, J. M., Price, K. R., Ridout, C. L., Johnson, I. T and Fenwick, G. R., 1989. Effects of Some Purified Saponins on Transmiral Potential Difference in Mammalian Intestines. Toxicol. Invitro. 3:85 90.

Hassan, L. G., Dangoso, S. M., Umar, U. J., Saidu, F and Folorunsho, F. A., 2008. Proximate, Mineral and Anit-nutritional Factor of Danella olvieri seeds kernel. Chem. Class. Journal 5:31 - 36.

Hatchison, J and Dalziel, J. M., 1958. Flora of West Tropical Africa. $\left(2^{\text {nd }}\right.$ ed) London, Crown Agents for Oversea Government and Administration.

Harborne, J. B., 1973. Phytochemical Methods, London, Chapman and Hill.

James, C. S., 1996. Analytical Chemistry of Food. New York, Chapman and Hall.

Kotoky, N., Dasgupta, B and Deka, N., 2005. Studies of Clerodendron Colebrookianun Walp. A poten Pharmacological hypertensive plant. Indian Journal of Physiol and Pharm. 49: 289 - 296.

Lovett, J. C., Ruffo, C. K., Gerau, R. E and Taplin, J. R. D., 2006. Field Guide to the Moist Forest Trees of Tanzania New York, New York Centre for Ecology, law and policy, environment Department, University of York, UK.

Mashana, N. R., Abbiw, D. K., Addae-Mensah, I. E., Adanouhonu, M. R., Ahyl, A. J., Ekpene, A. E., Enow Orock, G. Z., Gbile, O. G., Naomesi, K. M., Odei, A. H., Odunlani, A. A., Oten - Oteng-Yeboah, $\mathrm{K}$ and Tackie, A. N., 2000. Traditional Medicine and Phamacopocia: Contribution to the Revision of Ethno Botanical and Floristic Studies in Ghana. Accra.

Mohammed, A., Dangoggo, S. M., Tsafe, A. I., Hodo, A.

$U$ and Aliku, F. A., 2011. Proximate, Minerals and Anti nutritional Factors of Gardenia aqualla (Ganden dutse). Conference Proceeding of the $34^{\text {th }}$ Chemical Society of Nigeria $01-08$.

Munro, A and Bassir, B., 1969. Oxalate in Nigerian Vegetables. West African Journal of Biological and Applied Chemistry. 17: 14-18.
NRC., 1974. National Research Council, Recommended Dietary Allowance, Washington, D. C., National Academy Press.

Omarayi, P. O and Dilworth, L., 2007. Anti-nutritional Factors, Zinc, Iron and Calcium in some Cariggean Tuber Crops and Effect of Boiling or Roasting. Nutrition and Food Science, 37, (1): 8 -15 .

Oladokun, M. A., 1988. Fruit Characteristics of Cola lepidota (K. Schum). Nigerian Journal of Botany 2, (2): $58-60$.

Osabor, V. N., Egbung, G. E and Ntuk, U, M., 2010. Chemical Evaluation of the leaves of Diplazium summatti (Nyama Idim) Research Journal of Agriculture and Biological Science (6): 10741077.

Oyoyede, O. I., 2005. Chemical Profile of Unripe Pulp of Carica papaya, Pakistan Journal of Nutrition 4: $379-381$.

Oguntona, F., Oguntona, R. C and Williams, L., 1998. Survey of Food and Nutrient intake of Kanuri of Borno. Nigerian Savana, 10, (2): 86 - 91.

Pugalenthi, M., Vadievel, V., Guramoorthi, P and Janardharan, A., 2004. Comparative Nutritional Evaluation of little known legumes" Tamerindus indica, Erythrina indica and Sesbania bispinosa. Trop Subtrop Agroecosyst. (4): 107 - 123.

Robinson, C. H., 1978. Mineral Elements; in Fundamentals of Normal Nutrition. New York, McMillan publisher.

Scott, W. S., 1980. Water relations of Food Spoilage Micro process during Baking of African Bread Fruit (ABF) seeds. International Journal of food properties, 7:585-682

Saturdi, A. R and Suckle, K. A., 1985. Reduction of Phytic Acid levels in Soya Beans during Tempet Production of Drying and Storage. Journal of Food Science, (50): $260-261$.

Solomon, G and Crag, F., 1998. Organic Chemistry, New York John Wiley and Sons.

Trease, G. E and Evans, W. C., 1996. Pharmacognosy. London, Macmillan Publisher.

Ukpong, I. J and Akpan, M. E., 2011. Phytochemical Screening and Mineral Elements Composition of Cocoyam Inflorescence. Proceeding of the Chemical Society of Nigeria $34^{\text {th }}$ Annual International Conference, $122-124$.

Vogel, A. L., 1962. A textbook of Quantitative Inorganic Chemistry, London, Longman Groups. 
Wheeler, E. L and Ferrel, R. E., 1977. A Method of

Phytic Acid Determination in Wheat and Wheat Flour, Cereal Chemistry, 48, 313-34.

Zarkada, C. G and Voldenz, H. D., 1997. Determination of the Protein Quality of Three new Northern Adopted Cultivars of Common and Micro types Soya Beans by Amino acid Analysis. Journal of Agric. Food Chemistry, 45: 1161 - 1168. 